\title{
From Nuclear Hedging to Korea-Japan Nuclear Weapons Free Zone: Japan's Nuclear Options
}

\author{
TIANJIAO JIANG
}

\begin{abstract}
This article discusses both the positive and negative effects of Japan's three nuclear strategies: nuclear hedging, nuclear breakout, and the Korea-Japan Nuclear Weapons Free Zone (KJNWFZ). Nuclear hedging has been the longest established strategy to protect Japan's national security but it will become increasingly unreliable in the coming decades. Nuclear breakout, an alternative strategy, is impractical due to its high costs. In comparison, this article argues that KJNWFZ is the ideal option for Japan's future nuclear strategy. However, in recent years, the Japanese government has maintained the status quo, despite the scale of anti-nuclear protest across the country following the Fukushima crisis. Civilian anti-nuclear does not effectively influence nuclear strategy decision-making, due to a combination of national electoral politics, interests groups, the 'veto players' of the right-wing, and the broader regional security context. In conclusion, the nuclear hedging policy remains the accepted balance of interests supported by decision-makers.
\end{abstract}

Keywords: Japan, Nuclear Policy, Korea-Japan Nuclear Weapons Free Zone, Nuclear Hedging, Nuclear Breakout

\section{Introduction}

A combination of factors has brought the idea of 'nuclear free world' back to the horizon in recent years (White and Santoro 2012: 1). In the post-Cold War era, the traditional rationale for using nuclear weapons no longer retains salience or moral justification. Due to the proliferation of nuclear technology and fissile materials around the world, there is increasing concern about the potential for nuclear terrorist attacks. In response to the proliferation issue, nuclear deterrence is part of the problem, not its solution (Mack 1992); the establishment of Nuclear Weapons Free Zones (NWFZ) may provide a fundamentally different alternative. 
NWFZs seek to limit and delegitimise nuclear weapons in a gradual way: 'the 2006 Weapons of Mass Destruction Commission indicated that NWFZs filled important "gaps" in the NPT regime, as well as "complement and reinforce" it' (Taylor et al 2013: 80). The International Commission on Nuclear Non-Proliferation and Disarmament also strongly supported the utility of NWFZ. ${ }^{1}$ At the May 2010 Non-Proliferation Treaty (NPT) Review Conference, it was widely agreed that NWFZs had played an essential role in contributing to regional peace and the global agenda of non-proliferation (Davies 2010). ${ }^{2}$

Since the Northeast Asia region has been under the shadow of nuclear proliferation and the arms race for decades, there have been a number of proposals for the establishment of a Northeast Asia Nuclear Weapons Free Zone (NEANWFZ) in recent years. One of the most inspiring plans, arguing for the creation of the Korea-Japan Nuclear Weapons Free Zone (KJNWFZ), was proposed by the Nautilus Institute. Michael Hamel-Green, Peter Hayes and other scholars at the Nautilus Institute have been formative in discussions of the KJNWFZ. In this study, I examine the KJNWFZ from the perspective of Japan. I compare the new framework with Tokyo's current nuclear hedging policy and nuclear breakout as alternatives. In closing, I focus on Japan's security environment, domestic politics and nuclear policy decision-making process. As discussion of KJNWFZ from the Japanese perspective is still limited (Hayes 2010; Umebayashi 2013) ${ }^{3}$, I include a detailed analysis of the costs and benefits of the three nuclear strategies, and contend that the KJNWFZ seems to be a more effective and reliable strategy in the long term. With this in mind, it is puzzling to note that the Japanese government has not considered the KJNWFZ proposal more seriously, particularly given the rising anti-nuclear sentiment across the country following the Fukushima nuclear crisis and the 70th anniversary of the bombing of Hiroshima and Nagasaki.

I therefore aim to identify the strategic actors in Japan's nuclear decision-making and discuss their concerns about the available options. I use an international relations approach to describe the security threat Japan is facing and borrow the 'veto-players' model (Ganghof 2003; Tsebelis 2000; Hymans 2011) to reveal the decision-making circle. The theoretical framework encompasses both bureaucratic struggles and the regional security context as nuclear proliferation or restraint is not only about national security but is also determined through political debate and normative symbols (Sagan 1997). I also seek to explain how strategic players with particular security perceptions influence the deci- 
sion-making behind Japan's nuclear strategy. I contend that although the KJNWFZ plan has many advantages, the regional security dynamics render the idea of liberal institutionalism unconvincing. As most of the decision-makers respond to threats with a 'realist approach', nuclear hedging continues to serve the best interests of all strategic players.

This article has significant policy implications for the nonproliferation and security debates of Northeast Asia. By comparing the relatively new proposal of a nuclear weapons free zone with the better-known nuclear hedging and nuclear breakout policies, it provides a better understanding of Japan's nuclear strategy options and the calculation of costs and benefits. It also sheds light on the possibility of a nuclear weapons free zone as an alternative for regional security, given that North Korea conducted nuclear tests in 2013 and 2016 after the stalemate of the Six Party Talks. ${ }^{4}$ This study shows how states deal with the issues of nuclear proliferation and nuclear restraint by identifying strategic actors in the decision-making circle and revealing how both bureaucratic competition (internal) and threat perceptions (external) influence their preferences. Thus, it not only reveals the multi-causality of Japan's nuclear restraint but also, more importantly, explains Tokyo's reluctance to abolish its nuclear potential.

\section{The Korea-Japan Nuclear Weapons Free Zone (KJNWFZ) Initiative}

The idea of NWFZ in Northeast Asia is not new. In fact, there have been numerous references to the idea in the speeches and declaratory policies of the leaders of North Korea, the USSR, and the Socialist Party of Japan since the late 1970s (Kihl and Hayes 1997: 381). While the focus of previous NEANWFZ proposals has either concentrated on the Korean peninsula or covered the whole Northeast Asian region, an alternative way forward will be the initial establishment of a NWFZ between Japan and South Korea, with North Korea encouraged to join later. This is the proposal advanced by the Nautilus Institute's Korea-Japan Nuclear Weapons Free Zone (KJNWFZ) Concept Paper (Nautilus Institute 2010). ${ }^{5}$

Such a bilateral zone, with the door held open to North Korea to join at a later stage, would act as a circuit-breaker in the stalemated nuclear confrontation; prefigure a US negative security guarantee to North Korea in a future rapprochement; and reduce ongoing regional anxieties by locking both South Korea and Japan into a legally binding non-nuclear security posture. (Tanter and Hayes 2011: 16) 
The KJNWFZ initiative will be beneficial to Japan for several reasons:

1) The establishment of KJNWFZ will protect Japan's national security from nuclear strike or nuclear blackmail. Although the 'nuclear umbrella' provided by the US has to be removed according to the framework of NWFZ, it will provide compensating protection through negative security assurance (NSA) from both China and Russia, and positive security assurance from the United Nations Security Council. Since Tokyo has territorial disputes with Beijing and Moscow, the legally binding guarantees that both China and Russia cannot use or threaten to use nuclear weapons against Japan will be strategically essential (China has made 'no first use' a part of its nuclear principle as presented at the United Nations in 1995, but it is still a voluntary compliance).

2) Such zones will encourage both Tokyo and Seoul to reaffirm their commitments to remain non-nuclear so as to defuse any potential nuclear arms race. Both Japan and South Korea have the capacity to rapidly develop and acquire nuclear weapons. Even though the US is providing extended deterrence to protect Japan and South Korea, it is still possible that the further development of North Korea's nuclear capability could provide a pretext for either or both countries to acquire their own nuclear weapons (Green 2010). ${ }^{6}$ Due to the historical issues and territorial disputes with the South Korea, it would be the worst-case scenario for Japan to face two nucleararmed Koreas. However, the KJNWFZ plan would prevent this scenario permanently. It will also help dilute the mutual suspicion between Seoul and Tokyo, especially given the acceleration of the latter's remilitarization in recent years.

3) The KJNWFZ will also serve as a confidence-building measure to address the North Korean nuclear issue. While Pyeongyang continues to interlock nuclear weapons with its regime survival, the KJNWFZ will be an important inducement to the North to reconsider its security calculus (Green 2010). ${ }^{7}$ The removal of US extended deterrence and the legally binding non-nuclear status of both Japan and South Korea will reduce threat perceptions and rationales for North Korea's nuclear arsenal. Furthermore, since the door is open for a denuclearized North Korea to join the KJNWFZ at some point, it will address Pyeongyang's longstanding demand for nuclear reassurances within a multilateral framework and serve as a stepping-stone to improve relations with its neighbours (Sigal 2011: 35). There is always uncertainty about the future strategy of 
North Korea, but the KJNWFZ will certainly help to ease regional tensions and contribute to a long-term denuclearized outcome.

4) The establishment of KJNWFZ will increase Japan's soft power as a country following the path of peaceful development. It will not only dispel doubts held by regional players such as China and Korea, but also ease international suspicions about Japan's accumulation of plutonium and proactive remilitarization. As the only country to have suffered from the tragedy of nuclear attack, Japan has the moral authority to remind the world community of the precious sacrifices of Hiroshima and Nagasaki (Thakur 1998: 150). Through joining the NWFZ, Tokyo will take the leading role in the global agenda of non-proliferation.

5) Finally, the spillover effects of the KJNWFZ will be crucial to regional integration in the following decades. Despite the security interdependence of this region, there has been no multilateral security institution to sustain peace and stability. The Six Party Talks, which had been regarded as the most promising regional security framework to date, have been stalled for over five years. Under these circumstances, the working experience of KJNWFZ will promote cooperation and sustain mutual confidence in order to address other security issues. 'The vicious cycle of fear, mistrust and hostility sustaining open or ambiguous nuclear-weapons programs and postures can be replaced by the virtuous cycle of unequivocal non-nuclear status sustaining mutual confidence and cooperation' (Thakur 1998: 27). Through expanding the KJNWFZ into the NWFZ covering the whole Northeast Asia in the future, Tokyo will enjoy a great influence in regional affairs.

To implement the idea of KJNWFZ, the attitudes of other regional players will largely decide whether this kind of plan will prove feasible. The NSA from nuclear-weapon states is an indispensable part of a successful NWFZ framework.

It seems clear that both Russia and China will provide NSAs to Korea and Japan. It is in Moscow's interest to ensure the stability of the Far East and prevent further proliferation in the region. It is also essential for Beijing to have a stable regional order and the NSA is in accordance with its 'no-first-use' principle. There are some doubts as to whether Beijing is willing to give a legally binding guarantee to Japan but there are also some precedents. China accepted NSA to Kazakhstan in 1995 and confirmed it in 2004 in order to promote denuclearization and establishment of the NWFZ in Central Asia. China also provided the same 
NSA to Ukraine in 2013. It seems likely that Beijing is willing to grant NSA to more countries to protect the NPT regime and maintain regional stability. Since the KJNWFZ will not require Russia and China to reduce nuclear warheads and redeploy in their own territories, both countries will support the initiative so that they can lock the non-nuclear status of Japan and Korea as well as build trust with the North Korea at no cost.

The US may be concerned that the KJNWFZ will hinder its interest in free navigation, as American ships and aircraft carrying nuclear weapons will not be allowed into the zone. However, the potential benefits outweigh the disadvantages. A KJNWFZ will restrain the emergence of new nuclear-weapon states in Northeast Asia. After North Korea's nuclear test at the beginning of 2016, there has been a policy debate on whether the US should further pressure or re-engage North Korea as the 'strategic patience' failed (China File 2016; The Diplomat 2016; Huffington Post 2016). ${ }^{8}$ The KJNWFZ plan might serve as a new framework to help address the North Korea issue, establish mechanisms for engagement and dialogue, and restore mutual trust. President Barack Obama lent strong rhetorical support to creating a nuclear-weapons-free world and the KJNWFZ is also in line with the declaratory nuclear policy under his administration, which includes a firmer support of NSA (US, The White House: Office of the Press 2010). ${ }^{9}$ Although some might claim that the KJNWFZ was only attractive to the Obama administration due to the president's personal vision, it is arguably always in the US' interest to maintain the NPT regime, regardless of who the next president is. Despite the stir caused by Donald Trump's support for both Japan and South Korea developing nuclear weapons (The New York Times 2016), ${ }^{10}$ the KJNWFZ plan will not only be compatible with Trump's pulling back policy but will also prevent a nuclear domino effect in Northeast Asia. It would definitely promote the global Non-Proliferation Treaty (NPT) regime and might be utilized as a disarmament negotiation with Russia and China in the long term. Although the removal of extended deterrence seems a negative factor to the US alliance systems in Northeast Asia, it will anchor greater American conventional forces to play the pivotal role of regional balancer (Hayes and Bruce 2011: 84-85). Even if some member of the KJNWFZ violates the regulations or an extraordinary event takes place, the US can still withdraw from the treaty (as indicated in the Treaty on a Nuclear-Weapon-Free Zone in Central Asia and Protocols) and retrieve extended deterrence.

Last but not least, South Korea's attitude towards KJNWFZ is also critical. The recent nuclear test from Pyongyang has revitalized discus- 
sion about nuclear armament in Seoul (Washington Post 2016) ${ }^{11}$. However, triggering the nuclear domino might still be too risky for South Korea. In fact, besides the direct threat from the North, the complicated security environment has brought the South a number of strategic concerns, including the bilateral relations with Japan and its stockpile of plutonium, the reliability of the extended deterrence from the US, and relations with China and Russia as regional nuclear weapon states (Mack 1995: 107). Joining in the KJNWFZ is not an unrealistic option for South Korea, as most of these security concerns could be greatly improved. Concern about Japan's plutonium economy will be alleviated. Despite the removal of nuclear extended deterrence from the US, the legally guaranteed NSA will be provided as compensation. It will also serve as a confidence-building measure to restore the dialogue between South and North. Since South Korea is a loyal member of the NPT regime, its nuclear policy is completely in line with the KJNWFZ.

As discussed above, KJNWFZ is a feasible plan bringing strategic benefits to Tokyo in the long term. It will act as an essential circuitbreaker in the downward spiral of mistrust in Northeast Asia. It will serve to confirm the current non-nuclear-weapon status of Japan and South Korea, and replace the 'nuclear umbrella' with the NSA from nuclear-weapon states, while acting as a measure of confidence-building to make North Korea join such a zone later (Green 2011: 90-112). With the further development of the Northeast Asia Nuclear Weapons Free Zone in the future, Japan will not only protect itself from nuclear strike, but also gain leverage in anti-proliferation at both regional and global level. This is not to say that both Japan and South Korea should initiate the plan right now: bilateral relations are variable and there may not be political momentum to push for it. Nonetheless, the analysis above has demonstrated that the plan is practical and in line with Japan's strategic interests.

\section{The Problems of Current Nuclear Hedging Policy}

Compared with the relatively recent idea of the KJNWFZ, Japan has a long history of nuclear hedging policy since the beginning of the Cold War. Evelyn Goh defines hedging in general terms as 'taking action to ensure against undesirable outcomes, usually by betting on multiple alternative positions' (Goh 2005: 2). Levite defines nuclear hedging as 'a strategy lying between nuclear pursuit and nuclear rollback' (Levite 2002/3: 59). Tokyo regards a strategy of calculated ambiguity as its best 
option; it possesses nuclear capability on the one hand and remains committed to the Three Non-Nuclear Principles on the other. However, the extended deterrence from the US, which serves as the cornerstone of Tokyo's hedging, was weakened due to the Obama administration's ambitious vision of creating a world without nuclear weapons. With the continuing rise of China's military power, Japan's threat perceptions and abandonment anxiety will cast further doubts on the credibility of nuclear umbrella. Thus, the nuclear hedging policy will not be as effective as it once was, and an alternative framework will be considered to secure Tokyo's interests in the long term.

Throughout most of the Cold War, the Three Non-Nuclear Principles and the Four Nuclear Policies demonstrated Japan's official attitude towards the nuclear development. ${ }^{12}$ But a number of politicians and scholars have long been ambivalent about whether to acquire nuclear weapons:

Memories of horrific nuclear attacks on Hiroshima and Nagasaki have sustained anti-nuclear sentiment and helped justify national policies championing non-proliferation and forgoing an indigenous nuclear arsenal. This 'nuclear allergy' has been diagnosed as a genetic condition, and associated institutional and diplomatic constraints on nuclear breakout have been invoked to predict that Japan will find it virtually impossible to reverse course on nuclear weapons. (Tellis, Denmark and Tanner 2013: 233)

However, right-wing conservatives, like the former prime minister Nobusuke Kishi, argued that even the peace constitution did not prohibit Japan from building limited defensive nuclear weapons (Kishi 1957; Kishi 1967). The US commitment and capability to provide a nuclear umbrella in defence of Japan serve as preconditions for the latter's foregoing independent nuclear arsenal. But Tokyo has still developed an impressive civilian nuclear industry in order to possess a latent or 'virtual' nuclear capability (Wirtz and Lavoy 2012: 20). There is no doubt that the nuclear hedging strategy helps Japan achieve diversified or even contradictory goals. On one hand, it allows Japan access to fissile materials and technology support under the NPT regime, promoting the US-Japan alliance, and establishing the image of a peace-loving country. On the other, it still leaves a door open to nuclear breakout if the protection from the US proves unreliable in future; this position also appeases domestic hard-liners' desire for nuclear weapons. This explains why nuclear hedging has been adopted for such a long time as a strategy that meets the balance of interests.

Since the 1990s, in light of the nuclear and ballistic missile programmes of North Korea and the accelerating modernization of Chinese People's 
Liberation Army (PLA), regional security has become a growing concern for Japan. The strategic challenge posed by China together with North Korea provides motivation for reshaping Tokyo's strategic options and deterrent posture (Lee 2013: 24-26). The mainstream still favours a strong US-Japan alliance. But the confidence in US extended deterrence was shaken as Washington reduced the role of nuclear weapons, and moved to advance non-proliferation and disarmament (Wirtz and Lavoy 2012: 13-28). Japan expressed its worry that 'extended deterrence could weaken if Washington appears too eager to placate China and Russia on global disarmament issues in pursuit of the nonproliferation objective or if it permits a latent North Korean nuclear capability in exchange for safeguards against proliferation' (Schoff 2009: 59-78). Although US commitment and reliability have been reaffirmed through the annual US-Japan Security Consultative Committee and later the biannual event of Extended Deterrence Dialogue (EDD), there is still an obvious contradiction between Washington's objectives of non-proliferation and disarmament, and its commitment to providing extended deterrence.

In fact, the extended deterrence has many unsolved problems, which will become more challenging in the long term. As discussed above, Tokyo's reliance on extended deterrence corrodes its own disarmament diplomacy. On one hand, 'the voice of Japan calling for reduction and elimination of nuclear weapons is diminished because Japan is depending on the US nuclear umbrella' (Mizumoto 2004: 259). On the other hand, since US disarmament could trigger Japan's nuclear breakout, it would significantly slow down Washington's plan for global nuclear disarmament (Rublee 2010: 63). Moreover, the continuing extended deterrence would serve as a pretext for further nuclear proliferation.

The notion of extended deterrence itself has insinuated a false sense of security in the minds of many Japanese people (Lee 2013: 211). The so-called 'nuclear umbrella' exists only because the USA is pledged to defend Japan and happens to possess nuclear weapons (Lewis 2010; Tanter and Hayes 2011: 5-21). ${ }^{13}$ 'In the Nuclear Age... abandoning an ally risked eventual disaster, but resorting to war at the side of an ally guaranteed immediate catastrophe' (Kissinger 1994: 608). Many scholars have criticised extended deterrence as the US 'strategic insolvency' as the pursuit of 'yesterday's strategy under today's constraints' and the growing inability of the US to manage the gap between its strategic commitments and its national objectives (Mazarr 2012: 8). Arguably, '[E]xtended deterrence is a very risky business, and the US ought to have been glad to shed such commitments after the Cold War ended. 
Instead, the US retains extended deterrence commitments in Asia' (Posen 2013: 263).

Due to the increasingly contradictory and multiple roles required of extended deterrence, the whole region will be under the shadow of the 'security trilemma' instead of peace and stability. 'Actions taken by the US and its allies to deter or defend against North Korea may have the effect of making China feel less secure' (Posen 2013: 292-293). The US needs to not only assure Japan with extended deterrence but also reassure China that Washington is not pursuing regional hegemony. However, reassuring China is likely to worsen Japan's abandonment anxiety. Thus, the 'security trilemma' is an unstable status. As Posen notes:

China's ascendance in the region and its expanding military capabilities are of great concern to Tokyo in a longer-term, strategic sense. China's naval modernization, active missile program, and the impending development of the Jin-class ballistic missile submarine mean not only that China may continue to be assertive in maritime disputes but that it may soon possess a robust second-strike capability. (2013: 285)

If the US homeland became more vulnerable to Chinese nuclear attack, the Japanese might not believe that the US would take the risk of protecting its ally (Murdoch and Yeas 2009: 32-33).

In short, nuclear hedging is a very high-cost strategy, as extended deterrence needs to be reviewed frequently in its changing context. It not only contradicts the global agenda of non-proliferation and disarmament, but also leads to a 'security trilemma' in the region. With the rapid rise of China's maritime power and nuclear arsenal, the extended deterrence position will become increasingly untenable. Both the establishment of KJNWFZ and nuclear breakout could serve as alternative options, but the latter will face insurmountable obstacles and bring serious consequences.

\section{The Difficulties of Nuclear Breakout as an Alternative Option}

Since it is almost inconceivable that Japan could bandwagon with China in the near future, nuclear breakout would be a logical choice if the US standing commitment were weakening. Considering the territorial disputes with most regional players and the increasing threat from North Korea, some advocates of Japanese nuclear possession believe that it will be the most effective tool to protect national security. It will also enhance hard power, increase national prestige and make Japan a 'normal' coun- 
try. ${ }^{14}$ However, 'the path to a credible nuclear status is likely to be long and winding' (Yoshihara and Holmes 2012: 122). In addition to material, geographic, institutional and normative restraints, the consequences of Japan's nuclear breakout would be disastrous. Neither national security nor economic prosperity will be improved but would be threatened instead due to nuclear proliferation and the ensuing arms race.

While many believe that Japan possesses the technology to produce nuclear warheads in a matter of months, there are a number of reasons to suggest that this viewpoint is too optimistic. First and foremost, the costs of nuclear weapons are high. Although Japan has over 47 tons of reactor-grade plutonium (Japan Times 2014) ${ }^{15}$ - enough to make hundreds of thousands nuclear weapons, according to an internal report several years ago - it will take several hundred engineers, 2 to 3 billion USD, and three to five years to fabricate just one usable nuclear warhead (Yoshihara and Holmes 2012: 122). Then, owing to its lack of strategic depth and high population density, Japan will face the problem of finding nuclear test sites. Even if Tokyo possessed some nuclear weapons, the geographic limitations would massively reduce the credibility of its nuclear deterrent since most of its territory could hardly survive after a nuclear exchange (Thakur 1998: 147-148). Additionally, the Japanese government has signed various international treaties with International Atomic Energy Agency (IAEA) and bilateral safeguards agreements with the US, the UK, France, Australia and Canada. Unlike North Korea and Iran, it is almost impossible for Tokyo to bypass the international watchdog and develop nuclear weapons undetected. However, if Japan withdrew from the NPT and conducted nuclear tests publicly, the government would suffer not only diplomatic blowback but also domestic fury.

Even if Japan had successfully overcame all of these obstacles and possessed an independent nuclear arsenal, its nuclear breakout would bring about disastrous effects. A corollary of Tokyo's nuclear armament would definitely precipitate reinforcement of Pyeongyang's current nuclear programmes. Consequently, Seoul's breaking of its non-nuclear commitment would be justified. Under such circumstances, it would also be reasonable for Beijing to improve its nuclear deterrent, which might cause a nuclear breakout in Taiwan. Due to the chain reaction, there would be a serious nuclear arms race in Northeast Asia leading to further instability and disturbing economic cooperation. It seems obvious that such a scenario would contradict the reasons why Japan might pursue nuclear breakout. 
Finally, as one of the essential 'threshold states ${ }^{116}$ of the NPT regime, Japan's nuclear breakout would greatly damage the global agenda of disarmament and non-proliferation.

If Japan - the only country to be attacked with nuclear weapons, the only country to argue for nonproliferation and disarmament from a tragic historical experience, one of the main financial supporters of the regime - were to be seen as potentially withdrawing from the NPT, many other threshold states may wonder if the ship is sinking and whether it is time for them to leave as well. While we would probably not see a race to nuclearization, at the very least, most countries would wonder whether tackling the many difficult issues related to disarmament was worth it, given the Japanese defection. (Rublee 2010: 63)

In addition, Tokyo's nuclearization would undercut its close ties with the US. Since it is not in Washington's interests to deal with a nuclear arms race in Northeast Asia and to watch the end of the NPT regime, bilateral relations and security cooperation would suffer a profound blow. In sum, nuclear breakout, considered as one of Japan's strategic options, would bring danger rather than security. The path towards independent nuclear deterrent is full of difficulty and the consequences would seriously threaten Japan's national interests.

\section{The Intensification of the Anti-Nuclear Movement after Fukushima, and its Limitations}

According to the above theoretical evaluation, Japan's nuclear hedging policy will be unreliable in the long run and nuclear breakout would face insurmountable difficulties. In comparison, the KJNWFZ is the ideal plan for Japan's future security. However, the KJNWFZ or other similar NWFZ plans have never been regarded as serious alternatives by Japanese government; instead they are viewed only as proposals promoted by academic or non-government organisations. Even when the anti-nuclear movement intensified after the Fukushima nuclear crisis of 2011, the government still refused to change its nuclear policy. The agendas of recent National Diet (Kokkai legislature) elections, the decision-making processes guiding nuclear policy, the balance of power in the decision circle, and the national security perceptions of these strategic actors have all contributed to Japan's persistence with nuclear hedging. Although the anti-nuclear lobby has strengthened since Fukushima, interest groups and right-wing forces have successfully cited security and economic concerns to neutralize or suppress calls to curtail Japan's nuclear programme. 


\section{The Collaboration of 'Zero Nuclear Power' and the Anti- Nuclear Weapons Movement}

The populations of Hiroshima and Nagasaki have heartily supported former US president Barack Obama's vision of a world free of nuclear weapons. The mayors of both cities signed a document proposing to abolish nuclear weapons at the NPT Review Conference in 2020. Both have also tried various measures to broaden the influence of anti-nuclear weapons groups, including cooperating with international NGOs and bidding to host the Olympic Games. Japanese scholar Kodama Katsuya has coined the notion the of 'Hiroshima-Nagasaki Process', borrowed from the Ottawa Process and Oslo Process and their respective roles in the Mine Ban Treaty and International Convention Banning Cluster Bombs. He also pointed out that the A-bombing victims groups, NGOs and nonnuclear-weapon states would be key in implementing the Comprehensive Nuclear-Test-Ban Treaty, abolishing nuclear weapons and steadily establishing a global nuclear weapons free zone (Kodama 2010: 142-49).

The movement to abolish nuclear weapons in Japan has been mainly organised by left-wing groups since World War Two. Although there were nationwide anti-nuclear protests, especially in 1950s and 1960s due to the 'Gensuibaku' event, ${ }^{17}$ the past decades have witnessed the coexistence of the anti-nuclear movement and support for peaceful uses of nuclear energy.$^{18}$ However, since the Fukushima crisis, the traditional anti-nuclear weapons movement has collaborated with the 'zero nuclear power' movement in an unprecedented anti-nuclear effort (Kawasaki 2013: 593-614). Akira Kawasaki, executive committee member of the Tokyo-based NGO Peace Boat, pointed out that it is time to revive Japan's anti-war peace movement and learn the lessons of Fukushima. He considers it essential to connect the protests with campaigns of politicians and local government (Kawasaki 2011: 89-90). Takao Takahara, a professor from Meijigakuin University, argues that the Liberal Democratic Party (LDP) government obstinately maintains the nuclear umbrella and reprocessing of nuclear fuel, without considering the associated high risks (Takahara 2012: 129-31).

At the annual peace event held in Hiroshima and Nagasaki in August 2011, the mayors of both cities emphasised the dangers of using nuclear energy. Gensuikyo, the biggest anti-nuclear weapons organisation in Japan, has led other NGOs to join the lobby asking for 'zero nuclear power'. The Democratic Party of Japan (DPJ) government at that time launched a national debate on the nuclear energy issue and received a petition of 
over 90,000 names demanding the closure of all nuclear plants. In 2012, large crowds of protestors and NGO activists gathered before the prime minister's residence almost every week to protest against the restarting of nuclear plants after the crisis. The scale of these demonstrations consistently grew, with hundreds of thousands of people setting a new record for social movements in Japan. Over 60,000 people attended the protest in Tokyo in September 2011, 160,000 people in July 2012, and another 60,000 gathered in June 2013 (Kawasaki 2013: 598). In contrast to the post-war movement organised by left-wing groups, the new movement is beyond the left and right, and consists of people from all walks of life. A recent poll commissioned by Asahi Shimbun showed that nearly 60 per cent of respondents opposed the restart of nuclear plants due to the Fukushima crisis (Aldrich and Platte 2014; Asahi Shimbun 2013; Tsukimori 2013). ${ }^{19}$ More and more people have been reminded of the disaster brought by the atomic bombing (Lee 2013: 201). Even the hawkish Junichiro Koizumi and Morihiro Hosokawa criticised LDP's trying to restart the nuclear plants and called for 'zero nuclear power' (Sankei News 2014). ${ }^{20}$

The movement has spread across the country. From 2011 to 2014, the annual Praying for Peace event was organised in Hiroshima and Nagasaki by the Japanese Trade Union Confederation (JTUC) and other local governments including Kumamoto, Okayama, Chiba, Akita, and Hokkaido (Japanese Trade Union Confederation 2013; Japanese Trade Union Confederation 2015). ${ }^{21}$ The Research Center for Nuclear Weapons Abolition at Nagasaki University has launched a series of international conferences on the Northeast Asia Nuclear Weapons Free Zone since 2012 (Research Center for Nuclear Weapons Abolition 2015). ${ }^{22}$ The winner of the 1994 Nobel Prize in Literature, Kenzaburo Oe, has led several major anti-nuclear protests in Tokyo since 2011 (The New York Times 2012; The Japan Times 2013). ${ }^{23}$ Japan Peace Committee not only supported nationwide anti-nuclear campaigns, but also criticised Japan's nuclear policy and called for the establishment of a nuclear weapons free zone in its monthly magazine Peace Movement (Japan Peace Committee 2015). ${ }^{24}$ In 2014, there were more than 150 articles attacking the LDP's nuclear policy in Zenshin, the weekly magazine of Japanese Communist Party (Weekly Zenshin 2015). ${ }^{25}$ With the launch of the 2015 NPT Review Conference and the 70th anniversary of the Hiroshima and Nagasaki atomic bombing, the Gensuikin, Kakkin and JTUC have initiated activity to collect 10 million signatures calling for the abolition of nuclear weapons (Japanese Trade Union Confederation 2015). ${ }^{26}$ 
Although nuclear energy policy differs from nuclear weapons policy to some extent, the development of civilian nuclear technology is very closely connected with nuclear breakout, particularly in Japan (Fujita 2011). Former prime minister Nobusuke Kishi argued that the peace constitution did not forbid Japan holding limited defensive nuclear weapons and that the country had to possess the technology to build tactical nuclear weapons independently. To meet both military and civilian needs, the Kishi government decided to purchase the Calder Hall nuclear reactor from Britain in order to reduce Japan's dependence on nuclear technology transfer from the US, and to stockpile plutonium fuel for nuclear research or breakout in the future (Sato 2015: 29-48). Kishi did not only regard nuclear technology as an indispensable part of Japan's economic recovery and social development after the WW2, but also as crucial for potentially acquiring nuclear weapons, promoting international prestige and realising national independence. Declassified diplomatic archives from 1969 reveal that when the Japanese government was discussing whether to join the NPT, it was widely agreed that Japan should have the economic and technological potential to build nuclear weapons despite its non-nuclear-weapon status (Japanese Ministry of Foreign Affairs 1969a: 67-68). Even today, maintaining Japan's nuclear potential remains a major reason for the LDP government to restart nuclear plants post-Fukushima (Kono 2011: 84-85; Suzuki 2011: 178-79).

\section{National Diet Elections, Nuclear Policy Decision-Making and the Limitations of Anti-Nuclear Groups}

The unprecedented anti-nuclear protests after Fukushima have strengthened the 'nuclear allergy' in Japan, but have thus far failed to change the government's nuclear policy. Despite the anti-nuclear campaigns, the LDP has won several landslide victories in the National Diet elections and held its leadership since 2012. The reasons for this are as follows: 1) the Fukushima crisis happened during the DPJ's term and the party failed to deal effectively with the disaster due to its lack of experience and constraints from interest groups (Krauss 2013: 191-92). This was a heavy blow for the DPJ but a good opportunity for the LDP to regain the leadership at the next opportunity (Kingston 2013: 501-21); 2) since the political reform in 1994, the mixed-member majoritarian system has been accused of favouring LDP (Hrebenar 1986: 47) ${ }^{27}$ Furthermore, although most of the opposition parties support the realisation of 'zero nuclear power' and a nuclear weapons free zone as soon as possible 
(see Appendix II for reference), these newly emerging small parties have split the voters to counterattack the LDP (East Asia Forum 2014, 2015); ${ }^{28}$ and 3) in the past several elections, economic growth and security issues have proven to be more important to voters than the nuclear policy agenda (Kingston 2013: 501-21). The policy of 'Abenomics' brings hope for Japan's economy, which has experienced staggering growth for more than two decades. ${ }^{29}$ Shintaro Ishihara, a right-wing politician, made a speech in 2012 stating that he would represent the Japanese government to purchase the Diaoyu/Senkaku islands in order to end the territorial dispute between China and Japan. His island-buying move caused tension in bilateral relations, but was also a big opportunity for the LDP to speed up militarization. To cater to the right-wing, the Abe government further promoted historical revisionism, exercising the right of collective self-defence and reinterpreting the constitution. The continued tensions between Japan and China, and frequent provocations from North Korea, have made Abe's conservative policy more convincing. The result of the National Diet election in 2012 revealed that although the public was not satisfied with LDP's policy on nuclear energy, they still favoured Abe's LDP overall, thus marginalizing the anti-nuclear lobby in the political process.

The so-called 'nuclear village complex' in Japan, which consists of nuclear industry, bureaucratic agency and the National Diet, has monopolized technology and resources so as to make a closed decision circle in nuclear policy decision making. Lacking systemic political influence, civilian groups cannot get involved in the decision-making process. In contrast, according to Jacques Hymans' analysis of 'veto players' (see Ganghof 2003: 1-25; Tsebelis 2000: 441-74), the flexibility of Japan's nuclear policy depends on those decision-makers who have the veto power. If these veto players cannot reach consensus, there will not be any serious policy shift (Hymans 2011: 154-89).

From the perspective of nuclear energy policy, the 'zero nuclear power' campaign faces challenges from veto players, including the nuclear industry, power companies, the Ministry of Economy, Trade and Industry (METI) and Japan Atomic Energy Commission (JAEC). Interest groups like the Keidanren, Japan Chamber of Commerce and Industry, Japan Association of Corporate Executives and other big companies have continuously pressed to restart nuclear plants (Aldrich 2012: 2-5). Additionally, because of the increasing expense of imported energy, caused by the depreciation of the Yen, many people were worried about whether economic development can be sustained without a supply of 
nuclear energy. Hitachi, Toshiba and Mitsubishi as the global giants of nuclear energy are sparing no effort in promoting new projects, expanding exports and occupying market share (Dawson, Spegele and Williams 2012). ${ }^{30}$ One senior official from METI stated that as long as some countries still prefer nuclear power, Japan has to meet their needs. ${ }^{31}$ Finally, the JAEC rejects zero nuclear power, as this would render research into nuclear technology and the safety regulation of nuclear power unnecessary, and lead to the collapse of the commission.

Similarly, the anti-nuclear weapons campaign faces major challenge from the right-wing forces. The idea that possessing defensive nuclear weapons is in accordance with the Japanese constitution was put forward as early as 1957 by the Kishi government. Former prime minister Hayato Ikeda's 1961 cabinet also had many in favour of Japan possessing nuclear weapons (Sugita 2005: 81). Before joining the NPT, former prime minister Eisaku Sato stated that Japan should have nuclear weapons as long as other countries did (Asahi Shinbun 2005). According to declassified documents from the 1960s released by the Japanese Ministry of Foreign Affairs, it is clear that nuclear weapons were considered indispensable for dealing with China and for asserting Japan's position on the global stage (Yatabe 1968: 18). Since neither the Japanese 'nuclear allergy' nor the US-Japan alliance could be viewed as permanent, Japan should be prepared for nuclear breakout (Japanese Ministry of Foreign Affairs 1968: 13). In 1969, senior officials told the West German government that Japan would develop nuclear weapons if necessary (Japanese Ministry of Foreign Affairs 1969b).

Following the North Korean nuclear crisis in 1994, the Japanese government conducted internal research on whether to change its nuclear policy. In 1995, the report published by the Ministry of Defence pointed out that nuclear breakout would damage Japan's national interests and regional security. Despite this, in 1999 the vice-defence minister Shingo Nishimura argued that Japan should possess nuclear weapons (French 1999). ${ }^{32}$ Although Nishimura later resigned, his view was favoured by many politicians, including Keizo Obuchi (Japan Energy Scan 1999). ${ }^{33}$ In 2002, Ozawa Ichiro, the chief secretary of the LDP made a statement claiming that Japan was able to produce thousands of nuclear bombs and so did not fear China's military build-up. Then the chief cabinet secretary Yasuo Fukuda argued that the peace constitution did not forbid Japan from acquiring limited nuclear weapons to protect national security, and Shinzo Abe, then the vice-chief cabinet secretary, also believed there would be no problems so long as the nuclear weapons were limited 
in scale (Kakuchi 2002; French 2002) ${ }^{34}$ In 2004, former prime minister Yasuhiro Nakasone revealed in his memoirs that Japan had considered developing nuclear weapons back in the 1970s and that he himself also supported Japan having small nuclear weapons (Yoshida 2004). ${ }^{35}$ Two years later, the foreign minister Aso Taro and the chairman of the LDP's Policy Affairs Research Council (PARC) Nakagawa Shoichi attempted to initiate a debate on nuclear breakout (Hogg 2006), ${ }^{36}$ even arguing that the only way to deal with nuclear-weapon-states would be for Japan to possess its own nuclear weapons (Kyodo News 2009). ${ }^{37}$

Japan's right-wing conservatives have long hoped to possess nuclear weapons, in order to promote the country's political and military power. Those political groups in favour of nuclear breakout argue that, according to the Non-Proliferation Treaty (NPT), Tokyo retains the right to withdraw from NPT only when the country's core interests are threatened. Since there is no sign of denuclearization in North Korea, and China's development has raised tensions, those who support nuclear breakout see an opportunity (Panda 2014: 407-25). As the Koizumi government expanded the scope of the Self-Defence Force in 2004, and the Abe government has further expedited Japan's remilitarization (Hughes 2009a; Hook and Son 2013; Jo 2016), the right-wing influence on Japanese politics continues to grow. Since the KJNWFZ plan makes the alternative of nuclear breakout completely impossible, it would need to be overruled by these strategic actors or so-called 'veto players'.

\section{Japan's Security Environment and Threat Perception}

Since it is now almost impossible for Japan to realise nuclear breakout, the country's last resort of national defence is its US ally or international institutions like the NWFZ, which provides positive and negative security assurances. There is thus a debate over whether realists or liberal institutionalists can better improve national security. The KJNWFZ plan is the approach of choice for liberal institutionalism as it is based on international law and norms, the protection of the United Nations and commitment from nuclear-weapon-states, and the belief that institutions can alter states' preferences, promote cooperation and avoid conflicts. However, the realist camp $\mathrm{p}^{38}$ maintains that institutions, as a reflection of the distribution of power in the world, can hardly mitigate the international anarchy, which fosters competition and inhibits cooperation. From the realist perspective, nuclear weapons deter attacks and make war less likely (Sagan and Waltz 1995), so this camp argues for the development 
of nuclear weapons (self-help) or reliance on the 'nuclear umbrella' (alliance). The debate between realism and liberal institutionalism may never be resolved, but the state's nuclear choices are determined by the specific regional security context (Paul 2000). A closer examination of Japan's security environment and threat perception reveals why the KJNWFZ plan has not been convincing and why many strategic actors are in favour of nuclear hedging, despite its many problems.

Japan's current regional security context provides little basis for the liberalist position. In 2004, former prime minister Koizumi argued that 'the UN will not deploy forces to fight with Japan and prevent an invasion $^{139}$ if there were a critical incident. In contrast to Europe, the Cold War in Northeast Asia has not ended. Regional flash points such as the Korean Peninsula and the Taiwan Straits are perceived as existential threats to Japan. 'Given the lack of any collective security framework in Asia, the US bilateral alliance system remains the lynchpin of regional stability and security' (Cronin 2005: 71-72). Besides the strengthening of the US-Japan alliance, the closer strategic partnership of China and Russia, and the further development of North Korea's missiles and nuclear weapons, underpin 'the enduring emphasis on realism in Northeast Asia' (Rozman 2007: 280). Since all the regional players prefer the realist approach, Tokyo would struggle to offer a solid liberal response.

The power structures in Northeast Asia are pushing Japan towards a balancing strategy. Japan faces a great threat from North Korea due to nuclear weapons, missiles and the abduction issue of the 1970s and 80s. ${ }^{40}$ However, North Korea also serves as 'a catch-all proxy threat to justify changes in security policy that are simultaneously driven by the greater long-term, but diplomatically unacceptable to articulate, threat from China' (Hughes 2009b:311). Due to territorial disputes and the chain of events causing mutual distrust, Japanese public opinion polls in recent years reveal a growing perception of China as a threat (Watanabe 2015). ${ }^{41}$ At the official level, Japan's National Security Strategy of December 2013 identified China, alongside North Korea, as the major security challenge in Asia-Pacific. Japan is seriously concerned about China's attempts to change the regional status quo by force, escalating existing territorial disputes and establishing the Air Defense Identification Zone (ADIZ). ${ }^{42}$ Recent editions of Japan's defence reports have echoed this assessment. ${ }^{33}$ 'China's increasingly assertive regional behavior combined with a nontransparent military buildup' has influenced Japan's security policy shift towards expedited remilitarization (internal balance) and strengthening of the US-Japan alliance (external balance) (Ebert, Flemes and Struver 2014: 221). 
As Northeast Asia, haunted by geopolitical competition and lack of any regional security mechanism for decades, witnesses China's rise, it is natural for Japan to respond with a balancing strategy. Japan, as a secondary power in the region, seeks to maximize national security and reduce the relative advantage of its ascendant neighbour. Nuclear hedging is still the best-fit strategy, as it borrows deterrence from the US while keeping nuclear potential to convince China that any serious conflict or hegemonic behaviour may lead to nuclear acquisition in Japan.

While KJNWFZ would also provide defence through international institutions, it limits Tokyo's nuclear alternatives. If the plan is carried out, the stockpile of plutonium will become more problematic, and this might lead to the wipe-out of Japan's nuclear potential. The KJNWFZ plan does not fit Japan's realist logic of national strategy determined by the regional security context. This is why the KJNWFZ has failed to attract a majority of strategic actors in the decision-making circle and will never convince those conservatives who seek to make Japan a 'normal country'.

\section{Conclusion}

This article began with an exploration of Japan's nuclear strategic options, namely nuclear hedging, nuclear breakout and the establishment of a KJNWFZ. While the US-Japan alliance is in its best ever form, there is still analytical utility in considering the problems of extended deterrence in the long term. Extended deterrence will not only contradict the increasingly important global agenda of disarmament and nonproliferation, but will also lead to a 'security trilemma' in Northeast Asia. With the rapid rise of China's military power, the credibility of a nuclear umbrella will be seriously challenged. Consequently, Tokyo's current nuclear hedging policy will be out of date and a new framework will be necessary. Nuclear breakout will not be an ideal strategic alternative. Although Japan possesses advanced nuclear technology and large quantities of fissile materials, it will cost too much to produce nuclear warheads. In addition to geographic limitations, Tokyo will not bypass the international regulatory institutions and win the support of its domestic public, especially after the Fukushima crisis. Furthermore, the outcomes of a Japanese nuclear breakout would precipitate an arms race and great damage to the NPT regime. Neither national security nor economic prosperity will be enhanced through such a strategy. In theory, the KJNWFZ initiative is a wise strategic option. It would re- 
place the 'nuclear umbrella' with the NSA while serving as a measure of confidence-building to improve Japan's relations with both China and the two Koreas. It will not only protect Tokyo from nuclear strike and nuclear blackmail but also diffuse a potential regional arms race. The establishment of the KJNWFZ would correct Japan's incoherent nuclear diplomacy and increase its soft power as a peaceful state. It would also likely become a stepping-stone for multilateral security cooperation in Northeast Asia.

However, the Japanese government does not regard the KJNWFZ plan as a practical strategy and there have been few changes to nuclear policy, despite unprecedented anti-nuclear protests led by both peace organisations and the zero nuclear energy campaign after the Fukushima crisis. In the National Diet elections, the LDP won on agendas like economic growth and national security, despite the electorate's broad opposition to nuclear power. Civilian anti-nuclear groups failed to influence the political process effectively in the face of lobbying by the 'veto-players' in the nuclear policy decision-making circle. The nuclear industry, power companies and METI vetoed the zero nuclear energy policy, while the heavy industry and right-wing forces vetoed the KJNWFZ plan. Nuclear policy has been determined according to the balance of interests among 'veto players' for several decades and there is insufficient momentum for policy change or flexibility (Hymans 2011: 154-89). Last but not least, the regional security context also influences decision-makers' threat perception and limits Japan's nuclear options. As the shadow of the Cold War still lingers over Northeast Asia, China's rise leaves little scope for Japan to try its luck with the KJNWFZ. Instead, Japan sticks with the established nuclear hedging, in line with the grand strategy of balancing which convinces most strategic actors in the decision-making circle.

Tianjiao Jiang is a PhD candidate at the School of International Relations and Public Affairs, Fudan University. He is a member of International Student/ Young Pugwash (ISYP), CTBT Youth Group and Union of Concerned Scientists (UCS) Summer Symposium. His research focuses on nonproliferation and regional security in Northeast Asia. Email: tjiang09@fudan.edu.cn 


\section{NOTES}

1 Report of the International Commission on Nuclear Non-proliferation and Disarmament 2009. 'Eliminating Nuclear Threats: a Practical Agenda for Global Policymakers' pp.156-58. http://icnnd.org/Pages/default.aspx

2 Davies, Glyn 2010. 'US Ambassador to 2010 NPT Review Conference Statement'. http://www.reachingcriticalwill.org/images/documents/Disarmament-fora/npt/ revcon2010/statements/10May_MCII_United\%20States.pdf.

3 Hayes, Peter 2010. 'Korea-Japan Nuclear Weapon Free Zone (KJNWFZ) Concept Paper'. NAPSNet Special Report. http://nautilus.org/napsnet/napsnet-specialreports/korea-japan-nuclear-weapon-free-zone-kjnwfz-concept-paper/\#1-contactpeter-hayes Umebayashi, Hiromichi 2013. 'A Possible Approach for Establishing a Northeast Asia Nuclear-Weapon-Free Zone'. Research Center for Nuclear Weapons Abolition, Nagasaki University (RECNA), January 30. http:/ / www.recna.nagasakiu.ac.jp/recna/eyes/no2

4 The Six Party Talks consists of China, Japan, North Korea, South Korea, Russia and the USA, aiming to find a peaceful resolution to the North Korea nuclear issue. The first round of talks started in 2003. North Korea pulled out of the talks in 2009.

5 Nautilus Institute 2010. 'Korea-Japan Nuclear Weapon Free Zone (KJNWFZ) Concept Paper'. http://www.nautilus.org/initiatives/korea-japan-nwfz.

6 Green, Michael Hamel 2010. 'Implementing a Japanese-Korean Nuclear Weapon Free Zone: Precedents, Legal Forms, Governance, Scope and Domain, Verification and Compliance, and Regional Benefits'. Seoul: Nautilus Institute research workshop. http:/ / nautilus.org/wp-content/uploads/2011/12/Hamel-Green1.pdf.

7 The possible inducements for North Korean accession to a KJNWFZ would include: 1) the framework it offers (and with which in the past North Korea has expressed in principle agreement); 2) the concrete security benefits of potential security guarantees from the USA; 3) an inspection regime that would extend to US bases in South Korea and Japan; and 4) the prohibition of nuclear acquisition on the part of its two very nuclear-capable regional neighbours. Ibid.

8 China File 2016. 'What New Approach Should the U.S. and China Take to North Korea?' https://www.chinafile.com/conversation/what-new-approach-shouldus-and-china-take-north-korea The Diplomat 2016. 'US Policy Toward North Korea After the 2016 Nuclear Test: A Conversation With Joel Wit'. http://thediplomat. com/2016/01/us-policy-toward-north-korea-after-the-2016-nuclear-test-a-conversation-with-joel-wit/Huffington Post 2016. 'U.S. Should Engage Rather Than Isolate North Korea'. http://www.huffingtonpost.com/doug-bandow/us-should-engagerather-t_b_9109952.html

9 U.S. The White House: Office of the Press 2010. 'Statement by President Barack Obama on the Release of Nuclear Posture Review'. http:/ / www.whitehouse.gov/ the-pressoffice/statement-president-barack-obama-release-nuclear-posture-review.

10 The New York Times 2016. 'Transcript: Donald Trump Expounds on His Foreign Policy Views'. http://www.nytimes.com/2016/03/27/us/politics/donald-trumptranscript.html?_r=1

11 Washington Post 2016. 'As North Korea Flexes Its Muscles, Some in South Want Nukes, Too'. https://www.washingtonpost.com/world/asia_pacific/as-northkorea-flexes-its-muscles-the-other-korea-looks-at-nukes-too/2016/03/20/e2b1bb22eb88-11e5-a9ce-681055c7a05f_story.html

12 The Three Non-Nuclear Principles, which prohibit Japan from manufacturing, possessing, or permitting the entry of nuclear weapons into the air, land, or sea controlled by Japan. The Four Nuclear Policies constitute the second principle including adhering to the Three Non-Nuclear Principles, pursuing global nuclear 
disarmament, limiting the use of nuclear energy to peaceful purposes as defined by the 1955 Atomic Energy Basic Law, and relying on US extended deterrence that is codified by the 1960 US-Japan Security Treaty (Wirtz and Lavoy 2012).

13 Lewis, Jeffrey 2010. 'Rethinking Extended Deterrence in Northeast Asia'. http:// www.nautilus.org/publications/essays/napsnet/forum/2009-2010/rethinkingextended-deterrence.

14 Ichiro Ozawa's Blueprint for a New Japan (1994) started the debate on Japan's 'normalcy'. During the first Gulf War, Japan could not send troops but only provide financial support due to the constitution and legal impediments. Thus Japan was labeled as 'abnormal'. Many social elites especially the right-wing forces are trying to make the use of military as an instrument of foreign policy once again so that Japan could become a 'normal' country.

15 Japan Times 2014. 'Japan's Plutonium Stockpile Jumped to 47 Tons in 2013'. http:/ / www.japantimes.co.jp/news/2014/09/17/national/japans-plutonium-stockpilerose-47-tons-2013/\#.VITPFvldV2w.

16 A term commonly understood to mean possession of the indigenous ability to acquire nuclear weapons within a relatively short time frame, ranging from a few hours to several months. (Levite 2002-03: 66)

17 Daigo Fukuryu Maru, a Japanese tuna fishing boat, was exposed to and contaminated by nuclear fallout from the United States' Castle Bravo thermonuclear device test on Bikini Atoll, on March 1, 1954. The accident provoked large scale anti-nuclear protest in Japan.

18 Although there was a nationwide anti-nuclear campaign in the 1950s, many people still accepted the peaceful use of nuclear energy, which promoted economic development and advanced life quality. Not even the socialists challenged the use of nuclear energy (Kato and Ikawa 2013).

19 Aldrich, Daniel, and James Platte 2014. 'After the Fukushima Meltdown, Japan's nuclear Restart Is Stalled'. Washington Post (15 August 2014) http:/ /www.washingtonpost.com/blogs/monkey-cage/wp/2014/08/15/after-the-fukushima-meltdown-japans-nuclear-restart-is-stalled. Asahi Shimbun 2013. 'Asahi Poll: 59\% Oppose Abe's Nuclear Power Policy'. http://ajw.asahi.com/article/behind_news/politics/AJ201306100070. Tsukimori, Osamu 2013. 'Japan's Majority Favor Phasing-out Nuclear Power: Poll'. Reuters, http://www.reuters.com/article/2012/03/18/usjapan-nuclear-poll-idUSBRE82H01I20120318.

20 Sankei News 2014. 'Former Prime Minister Koizumi Challenged Restarting Nuclear Plant'. http:/ / www.sankei.com/politics/news/141022/plt1410220027-n1.html.

21 Japanese Trade Union Confederation 2013. '2013 Peace Movement in Hiroshima'. http://www.jtuc-rengo.or.jp/news/rengonews/2013/20130902_1378084994.html. Japanese Trade Union Confederation 2015. 'To Abolish Nuclear Weapons and Aid Victims'. http://www.jtuc-rengo.or.jp/rentai_katsudo/peace/kakuheiki/index. html\#030.

22 Research Center for Nuclear Weapons Abolition 2015. 'Approaches to Establish Nuclear Weapons Free Zone in Northeast Asia'. http://www.recna.nagasaki-u.ac. $\mathrm{jp} / \mathrm{recna} / \mathrm{asia}$.

23 The New York Times. 'Tokyo Rally Is Biggest Yet to Oppose Nuclear Plan'. http:/ / www.nytimes.com/2012/07/17/world/asia/thousands-gather-in-tokyo-to-protestnuclear-restart.html?_r=0. The Japan Times. 'Thousands Mass for Antinuclear Rally in Tokyo'. http://www.japantimes.co.jp/news/2013/10/13/national/thousandsmass-for-antinuclear-rally-in-tokyo/\#.Vw4HnDB97ct.

24 Japan Peace Committee 2015. 'Peace Movement Calendar'. Accessed June 11, 2015. http://j-peace.org/heiwaundo/. 
25 Weekly Zenshin 2015. 'Bikini Day Anti-nuclear Forum on March 1'. http://www. zenshin.org/zh/f-kiji/2015/02/f26680501.html.

26 Japanese Trade Union Confederation 2015. 'Sign the Petition for an End to All Nuclear Weapons'. http://www.jtuc-rengo.or.jp/rentai_katsudo/peace/syomei/index. html. Accessed 11 June 2015. See Appendix I for more campaigns organised by Japanese civilian groups and NGOs.

27 Simulation by the Asahi Newspaper showed that the LDP would increase its share of House seats from $55.2 \%$ to $78.9 \%$ under the mixed-member majoritarian electoral system (MMM) at that time.

28 East Asia Forum 2014. 'Election Reveals the Sorry State of Japan's Political Opposition'. http:/ / www.eastasiaforum.org/2014/12/18/election-reveals-the-sorry-stateof-japans-political-opposition/East Asia Forum 2015. 'The Rise and Fall of Japan's Opposition'. http://www.eastasiaforum.org/2015/09/16/the-rise-and-fall-of-japans-opposition/.

29 Abenomics refers to the economic policies advocated by Shinzo Abe since the December 2012 general election. Abenomics is based upon 'three arrows of fiscal stimulus, monetary easing and structural reforms. See Definition of Abenomics, Financial Times http:/ / lexicon.ft.com/Term?term=abenomics..

30 Dawson, Chester, Brian Spegele, and Selina Williams 2012. 'Nuclear Pushes on despite Fukushima'. Wall Street Journal (11 March), http://online.wsj.com/article/SB10001424052970204276304577265240284295880.html.

31 Ibid.

32 French, Howard W. 1999. 'Furor in Japan as Military Official Advocates Nuclear Weapons'. The New York Times, October 21, 1999. http://www.nytimes. com/1999/10/21/world/furor-in-japan-as-military-official-advocates-nuclearweapons.html

33 Japan Energy Scan 1999. 'Scholar Says Nishimura's Nuclear View Shared by Obuchi'. Highbeam Business, http:/ / business.highbeam.com/435557/article-1G1-57163110/ scholar-says-nishimura-nuclear-view-shared-obuchi.

34 Kakuchi, Suvendrini 2002. 'Politics-Japan: Discomfort Rises over Views on Nukes'. Inter Press Service (June), http://www.ipsnews.net/2002/06/politics-japan-discomfort-rises-over-views-on-nukes/. French, Howard W. 2002. 'Taboo Against Nuclear Arms Is Being Challenged in Japan'. The New York Times, June 9, 2002. http://www.nytimes.com/2002/06/09/world/taboo-against-nuclear-arms-is-being-challenged-in-japan.html

35 Yoshida, Reiji 2004. 'Japan Considered Developing Nukes: Nakasone'. The Japan Times, June 19,2004. http://www.japantimes.co.jp/2004/06/19/announcements/ japan-considered-developing-nukes-nakasone/

36 Hogg, Chris 2006. 'Abe Watched over Nuclear Debate'. BBC News, November 10, 2006. http://news.bbc.co.uk/2/hi/asia-pacific/6135992.stm

37 Kyodo News 2009. 'Nakagawa Floats Sobering Option: Going Nuclear'. The Japan Times, April 20. http://www.japantimes.co.jp/news/2009/04/20/national/nakagawa-floats-sobering-option-going-nuclear/\#.Vyl0z_197ct. Other discussions about Japan's nuclear acquisition, see NHK Special 'Japan's Pursuit of Nuclear: The Unknown Truth of the Contamination Country'. Tokyo: Koubunsha, January, 2012; Toshio Tamogami 'Even Monkeys Understand Japan's Nuclear Armament' Tokyo: Asukashinsha, August, 2009; Yatsuhiro Nakagawa 'The Options of Japan's Nuclear Armament' Tokyo: Tokumashoten, October, 2004; Terumasa Nakanishi Hencho 'The Issue of Japan's Nuclear Armament' Tokyo: PHP Kenkyujo, September, 2006.

38 'This essay does not distinguish between realism and 'neorealism,' because on crucial issues-the meaning of international anarchy, its effects on states, and the problem 
of cooperation-modem realists like Kenneth N. Waltz and Robert Gilpin are very much in accord with classical realists like E. H. Carr, Raymond Aron, and Hans J. Morgenthau.' See Grieco, Joseph M. 1988. 'Anarchy and the Limits of Cooperation: A Realist Critique of the Newest Liberal Institutionalism.' International Organization, 42 (3), pp.485-507.

39 Kyodo News 2004. 'Koizumi Cites U.S.-Japan Security Ties for Iraq War Support'. January 27.

40 During the 1970s and 1980s, a string of incidents occurred involving the abduction of Japanese citizens by North Korea. The Government of Japan has so far identified 17 Japanese citizens as victims of abduction. The abduction of Japanese citizens is a critical issue concerning the sovereignty of Japan and the lives and safety of Japanese citizens. Without the resolution of this issue, there can be no normalization of relations between Japan and North Korea. See Ministry of Foreign Affairs of Japan http://www.mofa.go.jp/region/asia-paci/n_korea/abduction/index.html.

41 Watanabe, Tsuneo. 2015. 'Japan's Security Strategy toward the Rise of China: From a Friendship Paradigm to a Mix of Engagement and Hedging', The Tokyo Foundation, April 6, http://www.tokyofoundation.org/en/articles/2015/security-strategytoward-rise-of-china

42 Cabinet Secretariat of the Japanese Central Government, 2013. 'National Security Strategy', pp. 12-13.

43 For example, See Japanese Ministry of Defense, 2015. 'Defense of Japan 2015 - Section 3 China'. http://www.mod.go.jp/e/publ/w_paper/pdf/2015/DOJ2015_1-1-3_web. pdf

44 All the information in this table can be found at: Japan Association of Disarmament Studies <http://www.disarmament.jp/index.html>, National Council of Japan Nuclear Free Local Authorities <http://www.nucfreejapan.com/kai_1.htm>, Japan Association of Lawyers Against Nuclear Arms <http://www.hankakuj.org/index.html>, Physicians Against Nuclear War <http://no-nukes.doc-net. or.jp/profile/prof_1.html>, All Japan Teachers and Staffs Union <http://www. zenkyo.biz/modules/general/index.php?id=89>, Japan Confederation of A- and H-Bomb Sufferers Organizations <http://www.ne.jp/asahi/hidankyo/nihon/ about/about1-01.html>, Soka Gakkai International <http://www.sgi.org/chs/ resource-center/introductory-materials/sgi-charter.html>, New Japan Women's Association <http://www.shinfujin.gr.jp/aboutus/aboutus.html>, Japan Peace Committee <http://j-peace.org/2011/heiwa_inkai.shtml>, Research Center for Nuclear Weapons Abolition, Nagasaki University <http:/ / www.recna.nagasaki-u.ac. jp/recna/about>, Hiroshima Municipal Government < http:/ / www.city.hiroshima. lg.jp/www/genre/1001000002088/index.html>, Nagasaki Municipal Government <http://www.city.nagasaki.lg.jp/heiwa/index.html>, Japan Council Against Atomic And Hydrogen Bombs <http://www.antiatom.org/>, Gensuikin Peace Forum <http://www.peace-forum.com/gensuikin/>. Accessed 12 June 2015.

45 All the information in this table can be found at: Japanese Communist Party, 'Initiative on Zero Nuclear Energy', <http:/ / www.jcp.or.jp/web_policy/2012/09/post473.html>; Japanese Communist Party, 'Outline of 2013 Upper House Election', <http://www.jcp.or.jp/web_policy/2013/06/2013-2.html>; Japanese Communist Party, 'Outline of 2012 National Diet Election', <http://www.jcp.or.jp/web_policy/2012/11/2012-37.html>; Japanese Communist Party, 'Outline of 2014 National Diet Election', <http://www.jcp.or.jp/web_policy/2014/11/post-659.html>; Social Democratic Party, 'Action Program of Energy Policy Reform,' <http:/ /www5.sdp. or.jp/policy/policy/eco/eco110420.htm>; Social Democratic Party, 'The Basic Law of Zero Nuclear Energy,' <http://www5.sdp.or.jp/policy/policy/energy/en- 
ergy130311.htm>; Social Democratic Party, 'Outline of 2014 National Diet Election,' <http://www5.sdp.or.jp/policy/policy/election/2014/commitment.htm\#1402>; Komeito, 'Initiative on Realizing Zero Nuclear World,' <https://www.komei. or.jp/policy/various_policies/pdf/kakuteigen.pdf>; People's Life Party and Taro Yamamoto and Friends, 'Outline of 2014 National Diet Election,' <http://www. seikatsu1.jp/policy/political_policy2014>; People's Life Party and Taro Yamamoto and Friends, 'Outline of 2013 Upper House Election,' <http://www.seikatsu1. jp/policy/political_policy>; Democratic Party of Japan, 'The Collection of Policies,' <http://www.dpj.or.jp/compilation/policies2013/50071>; Party for Future Generations, 'Basic Policy of Energy Supply,' <http://jisedai.jp/basicpolicy>; Ishinnotoh, 'Basic Policy of Nuclear Energy,' <https:/ / ishinnotoh.jp/policy/policy3/>; Liberal Democratic Party of Japan, 'The Collection of Policies,' <http://jimin.ncss. nifty.com/pdf/news/policy/126585_1.pdf>; Liberal Democratic Party of Japan, 'The Collection of Policies, J-File 2014,' <http://jimin.ncss.nifty.com/2014/political_promise/sen_shu47_j-file_1210.pdf >; Liberal Democratic Party of Japan, 'The Collection of Policies, J-File 2013,' http://jimin.ncss.nifty.com/pdf/sen_san23/jfile-2013-06-27-1.pdf. Accessed 12 June 2015.

\section{REFERENCES}

Aldrich, Daniel P 2012. 'Post-Crisis Japanese Nuclear Policy: From Top-Down Directives to Bottom-up Activism'. Asia Pacific 103: 2-5.

Asahi Shinbun 2005. 'The Argument of Nuclear Armament Surprised the U.S., Inquiry of Former Prime Minister Ikeda and Satou'. 1 August, No.12.

Cronin, Richard P. 2005. 'The North Korea Nuclear Threat and the U.S. - Japan Security Alliance: Perceived Interests, Approaches, and Prospects', The Fletcher Forum of World Affairs, 29 (1): 51-74.

Ebert, Hannes, Daniel Flemes and Georg Struver. 2014. 'The Politics of Contestation in Asia: How Japan and Pakistan Deal with Their Rising Neighbors'. The Chinese Journal of International Politics, 7 (2): 221-260.

Fujita, Yuko 2011. Fujita Yuko Verifies the Relations between Nuclear Power and Atomic Bomb. Tokyo: Honnoizumisha.

Ganghof, Steffen 2003. 'Promises and Pitfalls of Veto Player Analysis'. Swiss Political Science Review 9 (2): 1-25.

Goh, Evelyn 2005. Meeting the China Challenge: The U.S. in Southeast Asian Regional Security Strategies. Washington, D.C.: East-West Center.

Hamel-Green, Michael 2011. 'Implementing a Korea-Japan Nuclear-Weapon-Free Zone: Precedents, Legal Forms, Governance, Scope, Domain, Verification, Compliance and Regional Benefits'. Pacific Focus 26 (1): 90-112.

Hayes, Peter, and Scott Bruce 2011. 'North Korean Nuclear Nationalism and the Threat of Nuclear War in Korea'. Pacific Focus 26 (1): 65-89.

Hook, Glenn D, and Key-Young Son 2013. 'Transposition in Japanese State Identities: Overseas Troop Dispatches and the Emergence of a Humanitarian Power?'. Australian Journal of International Affairs 67 (1): 35-54.

Hrebenar, Ronald J. 1986. The Japanese Party System: From One-Party Rule to Coalition Government. Boulder: Westview Press.

Hughes, Christopher W. 2009a. Japan's Remilitarization. London: Routledge.

Hughes, Christopher W. 2009b. 'Super-Sizing' The DPRK Threat: Japan's Evolving Military Posture and North Korea, Asian Survey, 49 (2): 291-311.

Hymans, Jacques E.C. 2011. 'Veto Players, Nuclear Energy, and Nonproliferation: 
Domestic Institutional Barriers to a Japanese Bomb'. International Security 36 (2): 154-89.

Japanese Ministry of Foreign Affairs 1968. 'The Record of No.480 Foreign Policy Planning Committee Meeting' in diplomacy record released by Japanese Ministry of Foreign Affairs on November 29, 2010.

Japanese Ministry of Foreign Affairs 1969a. Wagakuni No Gaiko Seisaku Gaiyo 1969 (Outline of Japan's diplomatic policy 1969). Tokyo: Ministry of Foreign Affairs of Japan.

Japanese Ministry of Foreign Affairs 1969b. 'The Record of the First Japan-West Germany Policy Planning Discussion' (dated 6 February 1969; released by Japanese Ministry of Foreign Affairs on 29 November 2010).

Jo, Bee Yun 2016. 'Japan Inc.'s Remilitarization? A Firm-centric Analysis on Mitsubishi Heavy Industries and Japan's Defense Industry in the New-TPAE Regime'. International Relations of the Asia-Pacific 16 (1): 137-166.

Kato, Tetsuro, and Mitsuo Ikawa 2013. Nuclear Power and the Cold War: The Introduction of Nuclear Power into Japan and Asia. Tokyo: Kadensha.

Kawasaki, Akira 2011. 'Does Japan's Peace Movement Have a Future'. Sekai (September): 89-90.

Kawasaki, Akira 2013. 'Hopes and Traps on the Path to a Nuclear-Free Japan: The Fukushima Disaster and Civil Society'. Asian Perspective 37 (4): 593-614.

Kihl, Young Whan, and Peter Hayes (eds.) 1997. Peace and Security in Northeast Asia. New York: M.E. Sharpe.

Kingston, Jeff 2013. 'Nuclear Power Politics in Japan, 2011-2013'. Asian Perspective 37 (4): 501-21.

Kishi, Nobusuke 1957. Speech at the 26th National Assembly House of Councillors Budget Committee Meeting, Record No.24, May 7, p.21.

Kishi, Nobusuke 1967. The Recent International Situation. Tokyo: Kokusai Zenrin Kurabu.

Kissinger, Henry 1994. Diplomacy. New York: Simon and Achuster.

Kodama, Katsuya 2010. 'Hiroshima-Nagasaki Process'. Sekai (May): 142-49.

Kono, Taro 2011. 'Interview the Energy Policy Has to be Changed'. Sekai (June): 8485.

Krauss, Ellis 2013. 'Crisis Management, LDP, and DPJ Style'. Japanese Journal of Political Science 14 (2): 177-199.

Lee, Su Hoon, ed 2013. Northeast Asia's Nuclear Challenges. Changwon, South Korea: Institute for Far Eastern Studies Kyungnam University.

Levite, Ariel E 2002-03. 'Never Say Never Again: Nuclear Reversal Revisited'. International Security 27 (3): 59-88.

Mack, Andrew 1992. 'The Case for a Nuclear Weapon-Free Zone in Northeast Asia'. National Library of Australia Working Paper 8.

Mack, Andrew (ed.) 1995. Nuclear Policies in Northeast Asia. New York and Geneva: United Nations Institute for Disarmament Research.

Mazarr, Michael J 2012. 'The Risk of Ignoring Strategic Insolvency'. Washington Quarterly 35 (4): 8. In Ashley J. Tellis, Abraham M. Denmark, and Travis Tanner. (eds.) Strategic Asia 2013-14, Asia in the Second Nuclear Age. Washington D.C.: The National Bureau of Asian Research 2013: 262.

Mizumoto, Kazumi 2004. 'Non-Nuclear and Nuclear Disarmament Policies of Japan'. In Wade L. Huntley, Kazumi Mizumoto, and Mitsuru Kurosawa. (eds.) Nuclear Disarmament in the Twenty-First Century. Hiroshima: Hiroshima Peace Institute 2004: 259.

Murdoch, Clark A, and Jessica M. Yeas 2009. Exploring the Nuclear Posture Implications of Extended Deterrence and Assurance. Washington D.C.: Center for Strategic and International Studies. 
Panda, Rajaram 2014. 'Should Japan Go Nuclear?'. The Korean Journal of Defense Analysis 26 (4): 407-25.

Paul, Thazha Varkey 2000. Power versus Prudence: Why Nations Forgo Nuclear Weapons. Montreal: McGill-Queen's University Press.

Posen, Barry 2013. 'US Grand Strategy'. In Ashley J. Tellis, Abraham M. Denmark, and Travis Tanner (eds.) Strategic Asia 2013-14, Asia in the Second Nuclear Age. Washington D.C.: The National Bureau of Asian Research 2013: 263, 285, 292-93.

Rozman, Gilbert 2007. 'Reshuffling Priorities for Northeast Asian Security: Revisionism, Regionalism, Reunification, and Realism'. Korea Observer, 38 (2): 259-83.

Rublee, Maria Rost 2010. 'The Nuclear Threshold States: Challenges and Opportunities Posed by Brazil and Japan'. Nonproliferation Review 17 (1): 49-70.

Sagan, Scott D 1997. 'Why Do States Build Nuclear Weapons? Three Models in Search of a Bomb'. International Security, 21 (3): 54-86.

Sagan, Scott D and Kenneth Waltz 1995. The Spread of Nuclear Weapons: A Debate. New York: W. W. Norton \& Company.

Sato, Masashi 2015. 'Peaceful Uses of Atomic Energy and Nuclear Policy of Nobusuke Kishi'. Keiei Joho Kenkyu 22 (2): 29-48.

Schoff, James L 2009. 'Does the Nonproliferation Tail Wag the Deterrence Dog? PacNet 9'. Center for Strategic and International Studies. In Toshi Yoshihara and James R. Holmes. 'Thinking about the Unthinkable, Tokyo's Nuclear Option'. Naval War College Review 62 (3): 59-78.

Sigal, Leon V 2011. 'Political Prospects for a Nuclear-Weapons-Free Zone in Northeast Asia'. Pacific Focus 26 (1): 22-36.

Sugita, Hiroki 2005. The Options of Non-Nuclear: Follow the Field of Nuclear. Tokyo: Iwanamishoten.

Suzuki, Manami 2011. 'Is Fukushima the Turning Point of Nuclear Energy Policy'. Sekai (May): 178-79.

Takahara, Takao 2012. 'Doing away with the U.S. 'Nuclear Umbrella'?'. Annual Report of the Institute for International Studies 15 (December): 129-31.

Tanter, Richard, and Peter Hayes 2011. 'Beyond the Nuclear Umbrella: Re-Thinking the Theory and Practice of Nuclear Extended Deterrence in East Asia and the Pacific'. Pacific Focus 26 (1): 5-21.

Taylor, N. A. J., Joseph A. Camilleri and Michael Hamel-Green 2013. 'Dialogue on Middle East Biological, Nuclear, and Chemical Weapons Disarmament: Constraints and Opportunities'. Alternative: Global, Local, Political 38 (1): 78-98.

Tellis, Ashley J., Abraham M. Denmark, and Travis Tanner (eds.) 2013. Strategic Asia 2013-14, Asia in the Second Nuclear Age. Washington D.C.: The National Bureau of Asian Research.

Thakur, Ramesh, ed 1998. Nuclear Weapons-Free Zones. London: Macmillan Press.

Tsebelis, George 2000. 'Veto Players and Institutional Analysis'. Governance 13 (4): 441-74.

White, Tanya Ogilvie, and David Santoro 2012. Slaying The Nuclear Dragon. Georgia: University of Georgia Press.

Wirtz, James, and Peter René Lavoy 2012. Over the Horizon Proliferation Threats. California: Stanford University Press.

Yatabe, Atsuhiko 1968. 'NPT and Japan's National Security and Science and Technology' in diplomacy record released by Japanese Ministry of Foreign Affairs on November 29, 2010.

Yoshihara, Toshi, and James R. Holmes 2012. Strategy in the Second Nuclear Age. Washington D.C.: Georgetown University Press. 


\section{Appendix I Anti-Nuclear Organisations and Campaigns ${ }^{44}$}

\begin{tabular}{|c|c|c|}
\hline Organisation & Founded & Goal and Main Activities \\
\hline $\begin{array}{l}\text { Japan Association } \\
\text { of Disarmament } \\
\text { Studies }\end{array}$ & 2009 Tokyo & $\begin{array}{l}\text { Conducts research on non-proliferation and } \\
\text { disarmament, and spreads knowledge about } \\
\text { nuclear issues. }\end{array}$ \\
\hline $\begin{array}{l}\text { National Council of } \\
\text { Japan Nuclear Free } \\
\text { Local Authorities }\end{array}$ & $\begin{array}{l}1984 \\
\text { Hiroshima }\end{array}$ & $\begin{array}{l}\text { Calls for global campaign to abolish nuclear } \\
\text { weapons and promotes peace movement. }\end{array}$ \\
\hline $\begin{array}{l}\text { Japan Association } \\
\text { of Lawyers Against } \\
\text { Nuclear Arms }\end{array}$ & $\begin{array}{l}1992 \\
\text { Hiroshima }\end{array}$ & $\begin{array}{l}\text { Promotes signing the treaty to abolish nuclear } \\
\text { weapons and offers legal aid to the victims of } \\
\text { nuclear strikes or accidents. }\end{array}$ \\
\hline $\begin{array}{l}\text { Physicians Against } \\
\text { Nuclear War }\end{array}$ & 1987 Tokyo & $\begin{array}{l}\text { Protests against nuclear weapons and cooper- } \\
\text { ates with international and domestic peace } \\
\text { NGOs. }\end{array}$ \\
\hline $\begin{array}{l}\text { All Japan Teachers } \\
\text { and Staffs Union }\end{array}$ & 1991 Tokyo & $\begin{array}{l}\text { Campaigns to abolish nuclear weapons and } \\
\text { promotes peace movement. }\end{array}$ \\
\hline $\begin{array}{l}\text { Japan Confederation } \\
\text { of A- and H-Bomb } \\
\text { Sufferers Organisa- } \\
\text { tions }\end{array}$ & 1956 Tokyo & $\begin{array}{l}\text { Cooperates with domestic NGOs and inter- } \\
\text { national organisations on non-proliferation, } \\
\text { collects data and information about victims } \\
\text { of nuclear strikes and helps build museums } \\
\text { across the country. }\end{array}$ \\
\hline $\begin{array}{l}\text { Soka Gakkai Inter- } \\
\text { national }\end{array}$ & 1975 Tokyo & $\begin{array}{l}\text { Promotes abolishment of nuclear weapons and } \\
\text { realisation of a peaceful human society. }\end{array}$ \\
\hline $\begin{array}{l}\text { New Japan Wom- } \\
\text { en's Association }\end{array}$ & 1962 Tokyo & $\begin{array}{l}\text { Rejects nuclear weapons, which threaten the } \\
\text { wellbeing of women and children across the } \\
\text { world. }\end{array}$ \\
\hline $\begin{array}{l}\text { Japan Peace Com- } \\
\text { mittee }\end{array}$ & 1949 Tokyo & $\begin{array}{l}\text { Protects the peace constitution, promotes abol- } \\
\text { ishment of nuclear weapons, and organises an } \\
\text { annual anti-nuclear forum. }\end{array}$ \\
\hline $\begin{array}{l}\text { Research Center for } \\
\text { Nuclear Weapons } \\
\text { Abolition, Nagasaki } \\
\text { University }\end{array}$ & $\begin{array}{l}2012 \\
\text { Nagasaki }\end{array}$ & $\begin{array}{l}\text { Conducts research on non-proliferation and } \\
\text { disarmament, promotes the idea of Northeast } \\
\text { Asia Nuclear Weapons Free Zone, and spreads } \\
\text { knowledge about nuclear issues. }\end{array}$ \\
\hline $\begin{array}{l}\text { Hiroshima and } \\
\text { Nagasaki }\end{array}$ & & $\begin{array}{l}\text { Records the history of victims and builds local } \\
\text { peace museums to promote the abolishment of } \\
\text { nuclear weapons, organises peace movements. }\end{array}$ \\
\hline $\begin{array}{l}\text { Japan Council } \\
\text { Against Atomic } \\
\text { And Hydrogen } \\
\text { Bombs }\end{array}$ & 1954 Tokyo & $\begin{array}{l}\text { Campaigns against nuclear war and nuclear } \\
\text { weapons, and provides aid to the victims of } \\
\text { the A-bombs, including the annual World } \\
\text { Conference against A \& H Bombs, constant and } \\
\text { nationwide signature campaigns for a ban on } \\
\text { nuclear weapons, events and actions in cooper- } \\
\text { ation with the victims to make known the dam- } \\
\text { age of the A-bombings to the general public. }\end{array}$ \\
\hline $\begin{array}{l}\text { Gensuikin Peace } \\
\text { Forum }\end{array}$ & 1965 Tokyo & $\begin{array}{l}\text { Holds a peace conference every March and } \\
\text { promotes anti-nuclear power and anti-nuclear } \\
\text { weapons movement. }\end{array}$ \\
\hline
\end{tabular}




\section{Appendix II Japanese Political Parties' Positions on Nuclear Energy and Nuclear Weapons Issues after the Fukushima Crisis ${ }^{45}$}

\begin{tabular}{|c|c|c|}
\hline Party & Nuclear Energy Policy & Nuclear Weapons Policy \\
\hline $\begin{array}{l}\text { Japanese } \\
\text { Communist } \\
\text { Party }\end{array}$ & $\begin{array}{l}\text { To implement the zero nuclear } \\
\text { energy policy (Sep.25.2012); to } \\
\text { give up restarting nuclear plants, } \\
\text { close the Rokkasho Nuclear } \\
\text { Reprocessing Plant, forbid ex- } \\
\text { porting nuclear technology and } \\
\text { implement zero nuclear energy } \\
\text { policy (June.2013); stick to zero } \\
\text { nuclear energy policy (Novem- } \\
\text { ber 2014). }\end{array}$ & $\begin{array}{l}\text { To abolish nuclear weapons and } \\
\text { realize zero nuclear Japan (No- } \\
\text { vember 2012); to realize the zero } \\
\text { nuclear world and zero nuclear } \\
\text { Japan (November 2014). }\end{array}$ \\
\hline $\begin{array}{l}\text { Social Demo- } \\
\text { cratic Party }\end{array}$ & $\begin{array}{l}\text { To replace nuclear energy with } \\
\text { other new energy (April 20, } \\
\text { 2011); initiate the basic law of } \\
\text { anti-nuclear energy and cooper- } \\
\text { ate with other } 5 \text { parties in the } \\
\text { National Diet which won } 26 \text { sup- } \\
\text { ports (Sep.7.2012) }\end{array}$ & $\begin{array}{l}\text { To stick to the peace constitu- } \\
\text { tion and the Three Non-Nuclear } \\
\text { Principles, and promote Nuclear } \\
\text { Weapons Free Zone in Northeast } \\
\text { Asia (2014) }\end{array}$ \\
\hline Komeito & $\begin{array}{l}\text { To protest against restarting nu- } \\
\text { clear plants and replace nuclear } \\
\text { energy with other new energy. }\end{array}$ & $\begin{array}{l}\text { Komeito Chief Representative } \\
\text { Natsuo Yamaguchi attended the } \\
\text { Hiroshima peace event on Au- } \\
\text { gust 6, } 2014 \text { and issued an appeal } \\
\text { for the global abolition of nuclear } \\
\text { weapons. }\end{array}$ \\
\hline $\begin{array}{l}\text { People's } \\
\text { Life Party } \\
\text { and Taro } \\
\text { Yamamoto } \\
\text { and Friends }\end{array}$ & $\begin{array}{l}\text { To forbid restarting nuclear } \\
\text { plants and support research on } \\
\text { other new energy }\end{array}$ & $\begin{array}{l}\text { To stick to the peace constitution, } \\
\text { lead the global disarmament } \\
\text { agenda, and establish a peaceful } \\
\text { and zero nuclear world }\end{array}$ \\
\hline $\begin{array}{l}\text { Democratic } \\
\text { Party of } \\
\text { Japan }\end{array}$ & $\begin{array}{l}\text { To forbid restarting nuclear } \\
\text { plants and realize zero nuclear } \\
\text { energy (2013) }\end{array}$ & $\begin{array}{l}\text { To promote realizing the zero } \\
\text { nuclear world as the only victim } \\
\text { of the nuclear strike (2013) }\end{array}$ \\
\hline $\begin{array}{l}\text { Party for Fu- } \\
\text { ture Genera- } \\
\text { tions }\end{array}$ & $\begin{array}{l}\text { To have stable and secure energy } \\
\text { supply, develop new energy and } \\
\text { sustain advanced nuclear energy } \\
\text { projects; to get rid of nuclear } \\
\text { energy after having stable supply } \\
\text { from other new energy }\end{array}$ & \\
\hline Ishinnotoh & $\begin{array}{l}\text { To support research and de- } \\
\text { velopment of new energy and } \\
\text { establish new safety regulations } \\
\text { in order to restart nuclear plants }\end{array}$ & \\
\hline $\begin{array}{l}\text { Liberal Dem- } \\
\text { ocratic Party } \\
\text { of Japan }\end{array}$ & $\begin{array}{l}\text { To restore confidence in Japan's } \\
\text { nuclear industry, reform the } \\
\text { safety regulation, expand invest- } \\
\text { ment in the development of new } \\
\text { energy, and believe that nuclear } \\
\text { energy is still important in the } \\
\text { background of climate change }\end{array}$ & $\begin{array}{l}\text { Although Japan should lead } \\
\text { global disarmament agenda and } \\
\text { protect NTP regime, it is essen- } \\
\text { tial to have a comprehensive dis- } \\
\text { cussion on Japan's nuclear policy } \\
\text { in order to secure its national } \\
\text { interests. }\end{array}$ \\
\hline
\end{tabular}




\section{Appendix III 'Veto Players' in the Decision-Making Process of Japan's Nuclear Policy (based on Hymans 2011: 154-56)}

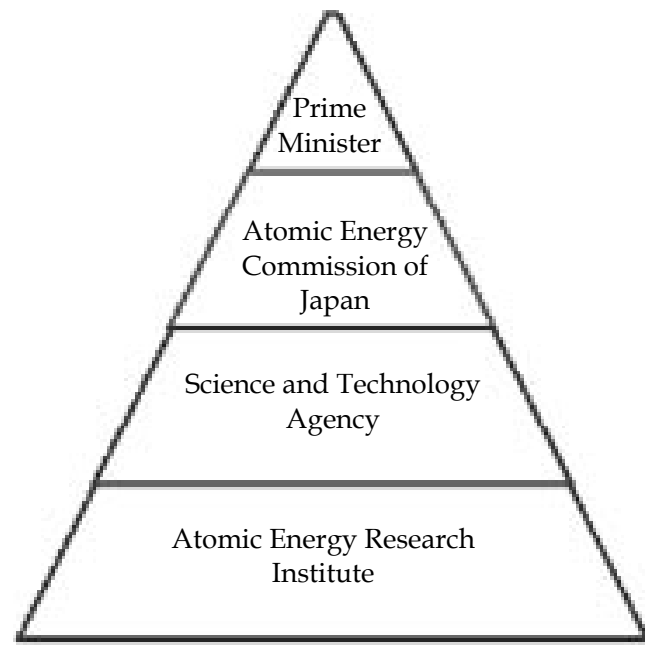

1950s

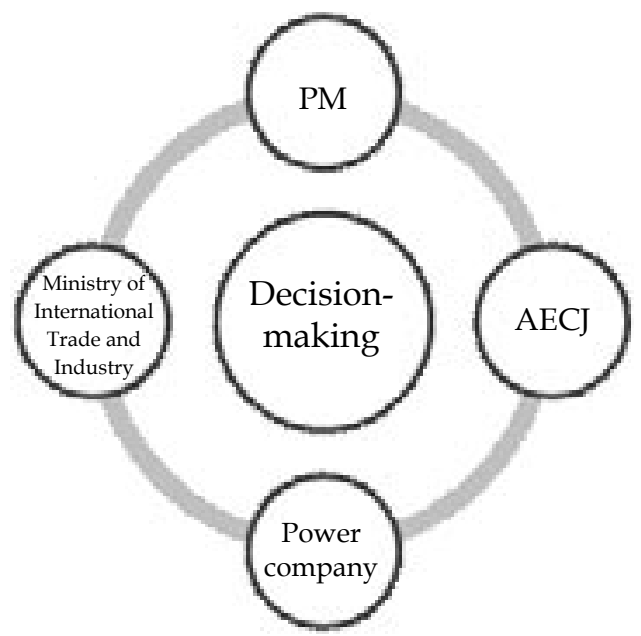

$1970 s$

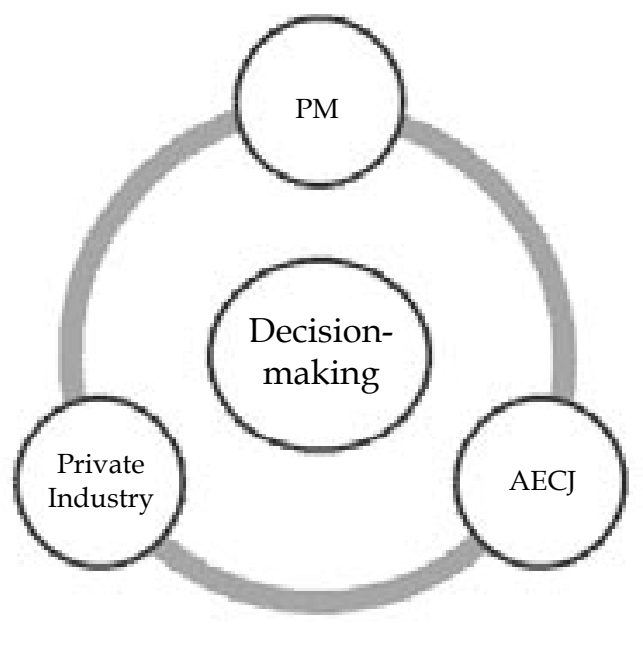

1960s

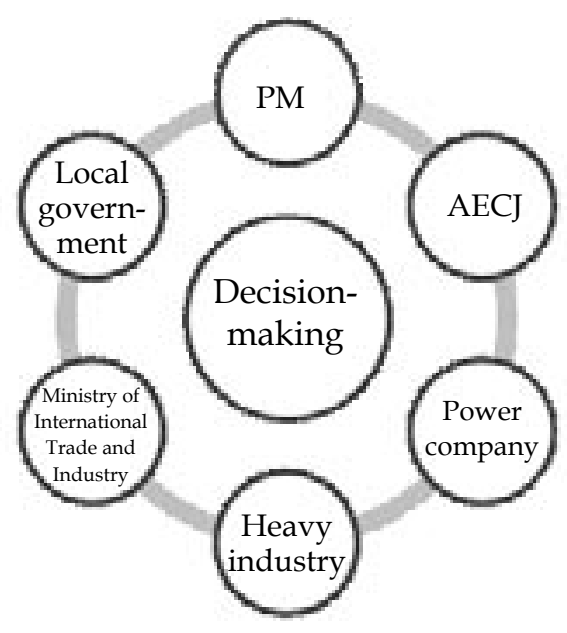

from 1990s 